\title{
Different cooking styles enhance antioxidant properties and carotenoids of biofortified pumpkin (Cucurbita moschata Duch) genotypes
}

\author{
Lara de Azevedo Sarmet MOREIRA¹, Lucia Maria Jaeger de CARVALHO ${ }^{1 *}$ (D), \\ Flávio da Silva e Souza Neves CARDOSO ${ }^{1}$, Gisela Maria Dellamora ORTIZ1, \\ Fernanda Dias Bartolomeu Abadio FINCO ${ }^{1}$, José Luiz Viana de CARVALHO ${ }^{2}$
}

\begin{abstract}
Biofortification is an important technique where the nutritional quality of food crops is enriched through the increase of nutrient content. Provitamin A deficiency is still a public health concern mainly in developing countries. Since beta-carotene is a vitamin A precursor, the increase of this compound in foods through biofortification is a manner to reach people under hidden hunger condition. This work aimed to evaluate the effect of different cooking styles on carotenoids content and antioxidant activity of two different genotypes of biofortified Cucurbita moschata. In the present study, biofortified pumpkins submitted to different cooking conditions were assessed for antioxidant activity by ABTS, DPPH, $\beta$-carotene/linoleic acid systems and have polyphenols and carotenoids content compared. The cooking style affected the antioxidant activity. Pumpkins from genotype 1 showed high levels of carotenoids, $\alpha$-carotene and all-E- $\beta$-carotene compared to samples from genotype 2 . There was an increase of all carotenoids in both cooked pumpkins, and steam cooking showed the highest retention percentages. Steam cooking presented a higher percentage of carotenoid retention. Pumpkin consumption in developing countries, especially in the Northeast Brazil may be promoted to combat vitamin A deficiency.
\end{abstract}

Keywords: pumpkin; antioxidant activity; carotenoids; cooking; biofortification.

Practical Application: The biofortified pumpkins are a low coast and easy cultivation crop with high carotene content which can be easily incorporated to diets of people experiencing hidden hunger.

\section{Introduction}

Vitamin A (retinol) deficiency is a public health problem that affects mostly children and poor women in developing countries. It occurs after prolonged lack of adequate dietary supply. The Carotenoids are probably the most frequent natural pigments. They can be found in animals, plants and microorganisms. Due to the presence of multiple conjugated double bonds, they are highly colored and lipophilic, featuring a variety of colors from yellow to intense red (Cardoso, 1997; Krinsky \& Johnson, 2005). The $Z$ isomers of provitamin $A$ are known for having lower vitamin A activity than the corresponding $E$ isomers. $\beta$-carotene occurs naturally in the all-E form, which is thermodynamically more stable and less soluble. Furthermore, it was found that all-E- $\beta$-carotene is absorbed preferentially to the $9-Z$ - $\beta$-carotene in humans.' BioFORT Project is coordinated by the Brazilian Research Agriculture Corporation (EMBRAPA) and responsible for scientific activities concerning food biofortification in Brazil which intends to contribute do undernutrition decrease and assure food and nutrition security to vulnerable populations. In Brazil, biofortification is applied consisting solely of genetic-enhancement techniques aiming at increase the micronutrients contents (including vitamin a) in the diet of people under vulnerable situation for micronutrient deficiency (BioFORT, 2018). Thereby, the interest in foods with high content of carotenoids with provitamin A activity ( $\beta$-carotene, $\alpha$-carotene e $\beta$-cryptoxanthin), such as pumpkins of Cucurbita genus, has increased substantially in recent years (Rodriguez-Amaya et al., 1988). Pumpkin is an excellent source of carotenoids with provitamin A activity. Cucurbita moschata is a widely cultivated specie, consumed in different regions of the world. However, its antioxidant potential is yet not well described and reported in the literature. Biofortified pumpkins genotypes (more nutritious) have been developed and cultivated focusing on decreasing malnutrition rates and ensure greater food security by increasing levels of vitamin A in the diet of vulnerable populations (BioFORT, 2018). The aim of this study was to evaluate the effect of different cooking techniques on carotenoids and antioxidant activity of biofortified pumpkins (C. moschata) aiming at providing scientific-based recommendation of the biofortified genotypes of pumpkins for cultivation towards food and nutrition security achievement of the target population of the BioFORT project (i.e. women and children) in the Northern and Northeastern Brazil. 


\section{Materials and methods}

\subsection{Reagents and standards}

Chromatographic grade solvents (acetone, petroleum ether, methanol, methyl tert-butyl ether and chloroform), Tween ${ }^{\circledR} 40$ and Celite 454 were purchased from Tedia (Fairfield, $\mathrm{OH}$ - USA). Analytical grade solvents (methanol, ethanol and ethyl ether) were purchased from Vetec (Rio de Janeiro, RJ - Brasil). 2,2-diphenylpicrylhydrazyl (DPPH), 2,2'-Azobis(2-methylpropionamidine) dihydrochloride (AAPH), potassium persulfate, fluorescein, sodium carbonate, gallic acid, trolox and Folin-Ciocalteau reagent were purchased from Sigma-Aldrich (St. Louis, MO - USA). 2,2'-azino-bis(3-ethylbenzothiazoline-6-sulphonic acid) (ABTS), $\beta$-carotene and linoleic acid were purchased from MP Bio (Solon, $\mathrm{OH}$ - USA). Nitrogen gas was purchased from White Martins (Rio de Janeiro, RJ - Brazil). BHT was purchased from Spectrum. The catalyst mixture for protein determination (Selenium Reagent Mixture GR for the determination of nitrogen) was purchased from Merck (Darmstadt - Deutschland).

\subsection{Samples}

Two different pumpkins genotypes (Cucurbita moschata) were cultivated in an experimental field of EMBRAPA Table Coastlands, located in Frei Paulo city (SE), from July to November of 2013. Fruits were harvested, and agronomic and nutritional characteristics were measured by the Biofortication program EMBRAPA. A sample of each genotype of biofortified pumpkins were forwarded to the Technology and Instrumental Analysis Laboratory in the Faculty of Pharmacy from the Federal University of Rio de Janeiro, Brazil. Genotype 1 presented the following measurements: $3.875 \mathrm{~kg} ; 13.8 \mathrm{~cm}$ in length and a width of $25.0 \mathrm{~cm}$, whereas genotype 2 was larger weighing $4.834 \mathrm{~kg}$, had $16.0 \mathrm{~cm}$ in length and $25.0 \mathrm{~cm}$ in width.

\subsection{Preparation of samples}

Pumpkins were washed with chlorinated water, dried and peeled. Each pumpkin was cut into small pieces (approximately $3 \mathrm{~cm}^{3}$ ) and randomly divided into three separate portions. One portion was kept raw, another was cooked in boiling water, and the third portion was steamed.

\subsection{Home cooking styles}

One portion of each pumpkin was cooked in boiling water $\left(100{ }^{\circ} \mathrm{C}\right)$ and the other was steam cooked. In both cases, $200 \mathrm{~g}$ of pumpkin flesh without seeds and $250 \mathrm{~mL}$ of boiling water were used. Samples were cooked for 5 minutes, since this is the usual time used in home cooking preparations. Cooked samples were water drained off, grinded and cooled $\left(-15^{\circ} \mathrm{C}\right)$ before extraction process.

\subsection{Nutritional composition}

The contents of moisture, fat, protein and ash were evaluated according to the Analytical Standards of Adolfo Lutz Institute (Instituto Adolfo Lutz, 2005) and total carbohydrates were determined by difference (NIFEXT). Results were expressed as $\mathrm{g} / 100 \mathrm{~g}$ of sample. The soluble solids were measured in an Abbe refractometer Biobrix 2WAJ (Shanghai, China) at $20^{\circ} \mathrm{C}$ (Instituto Adolfo Lutz, 2005).

\subsection{Total carotenoids, $\alpha$-carotene, $\beta$-carotene and isomers}

Procedures used for the carotenoids extraction and determination of Alpha-carotene, $\beta$-carotene and isomers by HPLC-DAD were based on the method of Rodriguez-Amaya and Kimura (Rodriguez-Amaya \& Kimura, 2004). Total carotenoids were estimated spectrophotometrically (at $450 \mathrm{~nm}$ ). A Waters 2695 Alliance chromatographic unit (Milford, United States) was coupled to a Waters 996 detector, network Diode UV/Visible $350 \mathrm{~nm}$ to $600 \mathrm{~nm}$, operated by Empower software. YCM Carotenoid C30 S-3 (4.6 mm x $250 \mathrm{~mm}$ ) reversed phase column was used to separate the compounds. The chromatographic analyses were performed using the following conditions: temperature of the jacket for the chromatographic column, $33^{\circ} \mathrm{C}$; flow rate, $0.8 \mathrm{~mL} /$ minute; injection volume, $15 \mu \mathrm{L}$; analysis time 28 minutes. Results were expressed in $\mu \mathrm{g} / \mathrm{g}$ of sample fresh weight (F.W.).

\subsection{Total phenolics}

Total phenolic content of the extracts was determined by the Folin-Ciocalteu assay. Folin-Ciocalteu reagent $(2.5 \mathrm{~mL}$ previously diluted 1: 10 in water) was added to $0.5 \mathrm{~mL}$ of extract, followed by addition of $2.0 \mathrm{~mL}$ of sodium carbonate $(75 \mathrm{~g} / \mathrm{L})$. Absorbance was measured at $760 \mathrm{~nm}$ using a Thermo Scientific Evolution 60 Spectrophotometer (Madison, United States).

\subsection{Antioxidant activity}

DPPH free radical scavenging activity was determined according to Scherer and Godoy (Scherer \& Godoy, 2009) using methanol is as solvent (Brand-Williams et al., 1995). ABTS radical scavenging activity was performed according to Re et al. (Re et al., 1999). The $\beta$-carotene/linoleic acid assay was performed as previously described by Marco (Marco, 1968) and modified by Miller (Miller, 1971). Absorbance was measured at $760 \mathrm{~nm}$ using a Thermo Scientific Evolution 60 Spectrophotometer (Madison, United States).

\subsection{Statistical analysis}

Each assay was independently carried out three times with the same extract. One-way analysis of variance was used to test any difference in outcome resulting from the different cooking techniques tested $(p<0.05)$. Tukey's test was used to determine significant differences between obtained means.

\section{Results and discussion}

The results of the nutritional composition of pumpkins are expressed in g. $100 \mathrm{~g}^{-1}$ of sample (Table 1). According to Pedrosa (1981) the variety of genotype 1 is a high quality fruit, with a high dry matter content (19.49\%), whereas genotype 2 is considered as having a low dry matter content (9.49\%). The moisture content of both pumpkins are similar to that previously reported (Jacobo-Valenzuela et al., 2011). However, Brazilian Table of Food Composition - TACO (Universidade 
Estadual de Campinas, 2011) lists a higher moisture content for other varieties of Cucurbita moschata Duch (Menina Brasileira and Pescoço). High dry matter contents give fruits greater value as raw materials (Ramos et al., 1999). In regard to previously reported data, genotype 1 showed the highest ash and carbohydrates contents, while genotype 2 showed higher protein concentration (Jacobo-Valenzuela, et al., 2011). Genotype 1 showed the highest values for soluble solids between the cooking styles $(p<0.05)$ (Table 1$)$. Soluble solids content was higher in the raw samples of both pumpkin genotypes in comparison to cooked samples, probably due losses by dissolution in the cooking water or steam. Maximum soluble solids content occurs at more advanced stages of maturation. Amounts $(\mathrm{mg} / \mathrm{g})$ of total carotenoids, $\alpha$-carotene, all- $E$-, $13-Z$ - and 9-Z- $\beta$-carotene present in raw and cooked pumpkins genotypes 1 and 2 are shown in Table 2. Total carotenoid content of genotype 1 is higher than in genotype 2 . The relatively high content of carotenes in genotype 1 is in accordance to that reported by Jacobo-Valenzuela et al. (2011) and markedly higher than other previously reported (Carvalho et al., 2012a, b). Considering that pumpkins genotypes were grown under the same cultivation conditions, the difference in total carotenoids content between genotypes 1 and 2 are most likely due to the differences in stage of maturity since genotype 1 has higher soluble solids content. E- $\beta$-carotene content exceeded $\alpha$-carotene content in pumpkins, and relatively minor amounts of 9 - and $13-Z \beta$-carotene were present in raw and cooked samples. Steaming had higher amount of $E-\beta C$ and $\alpha C$ than in boiled samples $(p<0.05)$. B-carotene content in pumpkins genotypes 1 and 2 are within the range reported by Jacobo-Valenzuela et al. (2011). Alpha-carotene content in genotype 1 , but not in genotype 2 , was higher than previously reported for $C$. moschata. (Carvalho et al., 2012b; Jacobo-Valenzuela et al., 2011) . In general, 13-Z- $\beta$-carotene contents were higher in cooked samples than in the raw ones, which is expected because cis-trans $(Z-E)$ isomerization is promoted by heating. The effects of cooking on the carotenoids content in vegetables is controversial, some authors report that cooking may result in carotenoids losses while others report their increase (Lessin et al., 1997; Rodriguez-Amaya \& Kimura, 2004; Rodriguez-Amaya \& Amaya-Farfan, 1992). This increase has been attributed to higher extraction efficiency since the heat treatment can inactivate oxidative enzymes and denature the complex between carotenoid and protein that exists in plant cells. Total phenolic compounds content in raw and cooked pumpkins are shown in Table 3. Total phenolic content was higher in raw genotype 2 in comparison to cooked samples

Table 1. Centesimal composition (in wet basis, g. $100 \mathrm{~g}^{-1}$ ) and soluble solids ( ${ }^{\circ}$ Brix) performed in triplicate in groups of preparations of pumpkins.

\begin{tabular}{|c|c|c|c|c|c|c|c|}
\hline Pumpkin & Cooking Style & Moisture & Ash & Protein & Lipids & Total Carb. & Soluble Solids \\
\hline \multirow[t]{3}{*}{1} & Raw & $80.83^{\mathrm{a}} \pm 0.01$ & $1.26^{\mathrm{a}} \pm 0.06$ & $1.12^{\mathrm{ab}} \pm 0.04$ & $0.8^{\mathrm{a}} \pm 0.04$ & 15.99 & $13.17 \pm 0.06^{\mathrm{a}}$ \\
\hline & Boiled & $84.51^{\mathrm{b}} \pm 0.18$ & $0.85^{\mathrm{b}} \pm 0.04$ & $0.83^{\mathrm{a}} \pm 0.12$ & $0.47^{\mathrm{b}} \pm 0.00$ & 13.34 & $9.80 \pm 0.10^{c}$ \\
\hline & Steamed & $82.25^{c} \pm 0.26$ & $1.06^{c} \pm 0.07$ & $0.89^{\mathrm{a}} \pm 0.04$ & $0.81^{\mathrm{a}} \pm 0.03$ & 14.99 & $12.13 \pm 0.12^{\mathrm{b}}$ \\
\hline \multirow[t]{3}{*}{2} & Raw & $90.51^{\mathrm{d}} \pm 0.09$ & $0.85^{\mathrm{b}} \pm 0.02$ & $1.41^{b c} \pm 0.04$ & $0.27^{c} \pm 0.00$ & 6.96 & $8.10 \pm 0.10^{\mathrm{d}}$ \\
\hline & Boiled & $91.44^{\mathrm{e}} \pm 0.16$ & $0.78^{\mathrm{b}} \pm 0.03$ & $1.30^{b c} \pm 0.12$ & $0.73^{\mathrm{a}} \pm 0.02$ & 5.75 & $6.20 \pm 0.00^{f}$ \\
\hline & Steamed & $89.94^{\mathrm{d}} \pm 0.04$ & $0.89^{\mathrm{b}} \pm 0.02$ & $1.47^{c} \pm 0.04$ & $0.79^{a} \pm 0.06$ & 6.91 & $7.73 \pm 0.06^{\mathrm{e}}$ \\
\hline
\end{tabular}

Each value represents the mean \pm standard deviation in triplicate; Different letters in the same column differ statistically $(P<0.05)$ by Tukey post-test.

Table 2. Total carotenoids, $\alpha$-carotene and $\beta$-carotene isomers (all- $E, 13-Z$ and $9-Z)(\mu \mathrm{g} / \mathrm{g}$ ) in raw and cooked pumpkins.

\begin{tabular}{|c|c|c|c|c|c|c|}
\hline Pumpkin & Cooking Style & Total Carotenoids & $\alpha$-carotene & All-E- $\beta$-carotene & 13-Z- $\beta$-carotene & 9-Z- $\beta$-carotene \\
\hline \multirow[t]{3}{*}{1} & Raw & $589.1^{b} \pm 6.74$ & $207.1^{b} \pm 6.99$ & $317.1^{\mathrm{b}} \pm 5.46$ & $7.8^{b} \pm 0.11$ & $6.5^{b} \pm 0.31$ \\
\hline & Boiled & $638.7^{\mathrm{a}} \pm 1.81$ & $214.5^{\mathrm{b}} \pm 3.80$ & $330.6^{\mathrm{ab}} \pm 4.03$ & $17.6^{\mathrm{a}} \pm 1.22$ & $7.1^{\mathrm{a}} \pm 0.12$ \\
\hline & Steamed & $655.3^{\mathrm{a}} \pm 10.73$ & $229.9^{\mathrm{a}} \pm 2.41$ & $339.6^{\mathrm{a}} \pm 8.06$ & $16.3^{\mathrm{a}} \pm 0.31$ & $5.2^{c} \pm 0.20$ \\
\hline \multirow[t]{3}{*}{2} & Raw & $234.4^{\mathrm{d}} \pm 1.26$ & $49.6^{c} \pm 1.21$ & $161.2^{\mathrm{d}} \pm 4.48$ & $3.2^{c} \pm 0.25$ & $2.9^{\mathrm{d}} \pm 0.25$ \\
\hline & Boiled & $242.50^{\mathrm{d}} \pm 8.53$ & $48.2^{c} \pm 1.52$ & $164.7^{\mathrm{d}} \pm 4.19$ & $7.3^{b} \pm 0.19$ & $2.2^{\mathrm{e}} \pm 0.15$ \\
\hline & Steamed & $274.9^{c} \pm 10.12$ & $55.6^{c} \pm 1.91$ & $191.60^{c} \pm 7.88$ & $7.04^{\mathrm{b}} \pm 0.24$ & $2.3^{\mathrm{d}} \pm 0.07$ \\
\hline
\end{tabular}

Each value represents the mean \pm standard deviation in triplicate. Different letters in the same column differ statistically (p $<0.05)$ by Tukey post-test.

Table 3. Total phenolic content in raw and cooked pumpkins (mg of Gallic acid per g of dry sample), and antioxidant capacity of methanolic extracts of raw and cooked pumpkins in dry basis using Trolox as standard.

\begin{tabular}{|c|c|c|c|c|c|}
\hline Pumpkin & Cooking style & $\begin{array}{l}\text { Total phenolic } \\
\text { compounds } \\
\text { (mg GAE/g) }\end{array}$ & $\begin{array}{c}\text { DPPH \% } \\
\text { (scavenging activity) }\end{array}$ & $\begin{array}{c}\text { ABTS } \\
(\mu \mathrm{M} \text { trolox } / g)\end{array}$ & $\begin{array}{l}\beta \text {-carotene / linoleic acid } \\
\text { (Oxidation inhibition \%) }\end{array}$ \\
\hline \multirow[t]{3}{*}{ Genotype 1} & Raw & $3.07 \pm 0.11^{b}$ & $3.91 \pm 0.09^{c}$ & $24.79 \pm 3.03^{b}$ & $38.63^{\mathrm{f}}( \pm 0.31)$ \\
\hline & Boiled & $1.70 \pm 0.04^{\mathrm{c}}$ & $6.01 \pm 0.23^{\mathrm{a}}$ & $22.89 \pm 1.01^{\mathrm{b}}$ & $45.13^{\mathrm{c}}( \pm 0.20)$ \\
\hline & Steamed & $1.75 \pm 0.01^{\mathrm{c}}$ & $5.46 \pm 0.26^{\mathrm{b}}$ & $23.83 \pm 1.78^{\mathrm{b}}$ & $44.59^{\mathrm{cd}}( \pm 0.28)$ \\
\hline \multirow[t]{3}{*}{ Genotype 2} & Raw & $4.10 \pm 0.01^{\mathrm{a}}$ & $4.20 \pm 0.09^{c}$ & $34.56 \pm 1.39^{\mathrm{a}}$ & $46.91^{\mathrm{b}}( \pm 0.16)$ \\
\hline & Boiled & $3.14 \pm 0.01^{\mathrm{b}}$ & $5.06 \pm 0.23^{b}$ & $34.15 \pm 1.30^{\mathrm{a}}$ & $42.94^{\mathrm{e}}( \pm 0.17)$ \\
\hline & Steamed & $3.10 \pm 0.01^{\mathrm{b}}$ & $5.41 \pm 0.17^{b}$ & $35.05 \pm 2.76^{\mathrm{a}}$ & $43.82^{\mathrm{d}}( \pm 0.15)$ \\
\hline
\end{tabular}

Each value represents the mean \pm standard deviation in triplicate. Different letters as superscripts in the same column differ significantly $(P<0.05)$ as determined by ANOVA followed by Tukey post-test; ABTS 2-2' -azino-bis (3-etilbenzotiazolin) 6-sulfônic acid; DPPH - 2,2-difenil-1-picrilhidrazil and GAE - Galic Acid Equivalent. 
regardless of cooking style. Phenolic contents similar to those obtained for genotype 2 (raw) were reported for the same pumpkin species (Jacobo-Valenzuela et al., 2011). Results for antioxidant activity are depicted in Table 3. DPPH scavenging activity of extracts from pumpkins ranged from 3.9 to $6.0 \%$ with the lowest activity being found for raw samples. In general, there was no significant difference $(p<0.05)$ between similar preparations of genotypes 1 and 2 (Table 3 ). Genotype 2 had higher antioxidant activity than genotype 1 , and this feature was not affected by cooking. Zhou \& Yu (2006) reported values for antioxidant activity assessed by the ABTS method for various vegetables. Finally, antioxidant activity was monitored using the $\beta$-carotene/linoleic acid model (Table 3). Genotype 1 showed a higher carotenoid content compared to genotype 2 and cooked preparations also had a higher content of these compounds. Therefore, it is possible that the antioxidant behavior exhibited in the $\beta$-carotene/linoleic acid system may be related to the carotenoid content in the samples. On the other hand, genotype 2 showed higher contents of phenolic compounds, especially the raw samples, also showing increased protection activity against oxidation compared to the preparations of cooked genotype 2 . It is possible that carotenoids were the compounds that most contributed to the antioxidant activity of genotype 1 in the $\beta$-carotene/linoleic acid system, whereas for genotype 2 , total phenolics may contributed to antioxidant activity obtained by ABTS method. This would explain the fact that cooked rather than raw genotype 1 had a higher antioxidant activity, while the inverse was true for genotype 2 .

\section{Conclusions}

In conclusion, the content of soluble solids of pumpkin genotypes allowed its classification as very mature (1) and mature (2), respectively. Genotype 1 presented the highest contents of $\beta$-carotene, probably due to the more advanced maturation stage. The antioxidant capacity (DPPH) increased after cooking although the levels were low. Results from the ABTS assay revealed higher antioxidant activity in samples of genotype 2 . Antioxidant activity of the biofortified pumpkin genotypes was higher to that reported in the literature for many other vegetables. The $\beta$-carotene/linoleic acid system method revealed that boiled samples of genotype 1 and raw genotype 2 were the ones with the highest antioxidant activities. The methods performed for the assessment of antioxidant activity presented different profiles according to the pumpkin sample and its preparations, which can be explained by the changes caused by cooking, by degradation of some compounds such as the phenolics or by increasing the availability of others like carotenoids as well. Considering that each method was more sensitive to different compounds, it was not possible to state that one methodology is better than another, since all have advantages and limitations. After cooking, there was an increase of all carotenoids in the two pumpkins samples. Steam cooking presented a higher percentage of carotenoid retention. The contents of polyphenols were reduced in all samples after cooking and genotype 2 presented the highest levels. Pumpkin consumption in developing countries, especially in the Northeast Brazil may be promoted to combat hidden hunger through vitamin A deficiency. Biofortified pumpkins may be consumed either steamed or boiled to enhance carotenoids accessibility.
The results of this study are promising, considering that $\beta$-carotene has $100 \%$ pro-vitamin A activity and may contribute to food and nutrition security achievement of vulnerable people in developing countries.

\section{Acknowledgements}

The authors thank HarvestPlus, Embrapa - Monsanto Research Fund for support of the BioFORT project and FAPERJ (Carlos Chagas Filho Foundation for Research Support of the State of Rio de Janeiro) for financial support of experiments conducted at the Federal University of Rio de Janeiro, and CAPES (Coordination for the Improvement of Higher Education Personnel, Brazil) for the fellowship of the first author.

\section{References}

BioFORT. (2018). Rede BioFORT. Retrieved from, from http://www. biofort.com.br/index.php?option=com_content\&view=article\&id $=76$ :redebiofort\&Itemid $=105$

Brand-Williams, W., Cuvelier, M. E., \& Berset, C. (1995). Use of a free radical method to evaluate antioxidant activity. LebensmittelWissenschaft + Technologie, 28(1), 25-30. http://dx.doi.org/10.1016/ S0023-6438(95)80008-5.

Cardoso, S. L. (1997). Fotofísica de carotenóides e o papel antioxidante de $\beta$-caroteno. Quimica Nova, 20(5), 535-540. http://dx.doi.org/10.1590/ S0100-40421997000500014.

Carvalho, L. M. J., Gomes, P. B., Godoy, R. L. O., Pacheco, S., do Monte, P. H. F., Carvalho, J. L. V., Nutti, M. R., Neves, A. C. L., Vieira, A. C. R. A., \& Ramos, S. R. R. (2012a). Total carotenoid content, $\alpha$-carotene and $\beta$-carotene, of landrace pumpkins (Cucurbita moschata Duch): A preliminary study. Food Research International, 47(2), 337-340. http://dx.doi.org/10.1016/j.foodres.2011.07.040.

Carvalho, P., Peixoto, A., \& Ferreira, M. (2012b). Caracterização de abóboras quanto aos teores de carotenóides totais, alfa- e betacaroteno. Boletim de Pesquisa e Desenvolvimento, 78, 20.

Instituto Adolfo Lutz - IAL. (2005). Normas analíticas do Instituto Adolfo Lutz. Métodos Físico-químicos para Análise de Alimentos do Instituto Adolfo Lutz (4th ed.). Brasília: Ministério da Saúde, Agência Nacional de Vigilância Sanitária.

Jacobo-Valenzuela, N., Maróstica-Junior, M. R., Zazueta-Morales, J. J., \& Gallegos-Infante, J. A. (2011). Physicochemical, technological properties, and health-benefits of Cucurbita moschata Duchense vs. Cehualca: a Review. Food Research International, 44(9), 2587-2593. http://dx.doi.org/10.1016/j.foodres.2011.04.039.

Krinsky, N. I., \& Johnson, E. J. (2005). Carotenoid actions and their relation to health and disease. Molecular Aspects of Medicine, 26(6), 459-516. http://dx.doi.org/10.1016/j.mam.2005.10.001. PMid:16309738.

Lessin, W. J., Catigani, G. L., \& Schwartz, S. J. (1997). Quantification of cis-trans Isomers of Provitamin A Carotenoids in Fresh and Processed Fruits and Vegetables. Journal of Agricultural and Food Chemistry, 45(10), 3728-3732. http://dx.doi.org/10.1021/jf960803z.

Marco, G. J. (1968). A rapid method for evaluation of antioxidants. Journal of the American Oil Chemists' Society, 45(9), 594-598. http:// dx.doi.org/10.1007/BF02668958.

Miller, H. E. (1971). A simplified method for the evaluation of antioxidants. Journal of the American Oil Chemists' Society, 48(2), 91-91. http://dx.doi.org/10.1007/BF02635693. 
Pedrosa, J. F. (1981). Caracterização agronômica e qualitativa de plantas e frutos de introdução de Cucurbita maxima e Cucurbita moschata (Master Thesis). Universidade de Viçosa, Viçosa.

Ramos, S. R. R., Queiroz, M. A., Casali, V. W. D., \& Cruz, C. D. (1999). Recursos genéticos de Cucurbita moschata: caracterização morfológica de populações locais coletadas no Nordeste brasileiro. In M. Queiroz, C. Goedert \& S. Ramos (Eds.), Recursos genéticos e melhoramento de plantas para o Nordeste brasileiro. Brasília: Embrapa Semi-Árido.

Re, R., Pellegrini, N., Proteggente, A., Pannala, A., Yang, M., \& RiceEvans, C. (1999). Antioxidant activity applying an improved ABTS radical cation decolorization assay. Free Radical Biology \& Medicine, 26(9-10), 1231-1237. http://dx.doi.org/10.1016/S0891-5849(98)003153. PMid:10381194.

Rodriguez-Amaya, D. B., \& Amaya-Farfan, J. (1992). Current status of analytical methods for measuring provitamin A. Archivos Latinoamericanos de Nutricion, 42(2), 180-191. PMid:1341859.

Rodriguez-Amaya, D. B., Kimura, M., Godoy, H. T., \& Arima, H. K. (1988). Assessment of provitamin A determination by open column chromatography/visible absorption spectrophotometry. Journal of Chromatographic Science, 26(12), 624-629. http://dx.doi.org/10.1093/ chromsci/26.12.624. PMid:3230117.

Rodriguez-Amaya, D., \& Kimura, M. (2004). HarvestPlus handbook for carotenoid analysis (HarvestPlus Technical Monograph Series, Vol. 2). Washington: International Food Policy Research Institute and International Center for Tropical Agriculture.

Scherer, R., \& Godoy, H. T. (2009). Antioxidant activity index (AAI) by the 2,2-diphenyl-1-picrylhydrazyl method. Food Chemistry, 112(3), 654-658. http://dx.doi.org/10.1016/j.foodchem.2008.06.026.

Universidade Estadual de Campinas - UNICAMP. (2011). Tabela Brasileira de Composição de Alimentos-TACO (4th ed., Vol. 2018). Campinas: UNICAMP/NEPA.

Zhou, K., \& Yu, L. (2006). Total phenolic contents and antioxidant properties of commonly consumed vegetables grown in Colorado. Lebensmittel-Wissenschaft + Technologie, 39(10), 1155-1162. http:// dx.doi.org/10.1016/j.lwt.2005.07.015. 